\title{
Vulnerability index for risk evaluation: an approach for safety on dams in downstream valleys
}

\author{
T. Viseu ${ }^{1} \&$ A. B. de Almeida ${ }^{2}$ \\ ${ }^{1}$ National Laboratory of Civil Engineering, Portugal \\ ${ }^{2}$ Technical University of Lisbon, Portugal
}

\begin{abstract}
Part of the losses that occur in a flood prone area depend on the flood characteristics, especially on the flood level of danger which is directly linked to the values of water depth and flow velocity, as well as the time of the flood arrival. The other losses depend on the vulnerability of the flood prone area. However, in real situations the conditional objective probabilities related to losses and hydrodynamic characteristics are very difficult obtain. A nonprobabilistic methodology to estimate this operator, which affects human lives as well as economical and environmental losses in the downstream valley, is presented, through the development of a downstream valley vulnerability index. The calculation of the vulnerability index is performed by a simple computer application using MS Excel software from Microsoft. The determination of the index vulnerability of a Portuguese dam valley is also performed.
\end{abstract}

Keywords: vulnerability, loss of life, damages, index, flood, flood prone area.

\section{Introduction}

The ageing of dams, changes in hydrologic conditions and the increasing population in valleys justify there being greater attention paid to dam safety and valley management. Potential dam failures, as well as the public pressure for a safer environment in contemporary society, make the risk evaluation of downstream valleys mandatory.

In the case of a dam failure, the downstream valley risk evaluation depends on the event probability of occurrence $(P(E i))$ and on the conditioned probability 
of dam failure once the event occurred $\left(P\left(Q_{P} / E_{i}\right)\right)$. A third probability, depending on a valley's characteristics, can affect the amount of loss which is related to the human level of survival as well as to the resistance of buildings: the conditioned probability of occurrence of $N$ losses once the dam has failed $\left(P\left(N / Q_{P}\right)\right)$. Therefore the mathematical expression for risk evaluation in dam downstream valleys $\left(R_{\text {valley }}\right)$ is as follows (Almeida et al. [1]):

$$
R_{\text {valley }}=P\left(E_{i}\right) \int_{0}^{N_{\max }} \int_{0}^{Q_{\max }} P\left(Q_{p} / E_{i}\right) P\left(N / Q_{p}\right) N d Q d N
$$

It is possible to relate the third probability in eqn (1) with downstream valley vulnerability. In fact, if part of the damage that occurs in a flood prone area depends on the flood characteristics, the other part is closely affected by the social and economical characteristics of the population at risk and its level of preparedness, as well as by the level of resistance of the buildings in the flood prone area. All the previous characteristics, which can increase the level of survival and diminish the damage, define the vulnerability of the population and of the area that can be affected by the flood.

\section{Vulnerability index}

In this paper, the vulnerability index is obtained by a weighted sum of four sub-indexes concerning the following components:

- $\quad$ the physical features of the building constructed in the flood prone area, expressed by the physical household vulnerability sub-index $I_{\text {edi }}$;

- the demographic characteristics of the population at risk, expressed by the demographical vulnerability sub-index, $I_{s o c}$

the economical characteristics on the flood prone area, expressed by the economical vulnerability sub-index, $I_{\text {eco }}$;

the preparedness of the civil protection agents as well as of the general population living in the flood prone area, which is expressed by the preparedness vulnerability sub-index, $I_{\text {prep }}$.

The vulnerability index, $I_{v u l n}$, is expressed by a percentage varying from $0 \%$ (no vulnerability) to $100 \%$ (total vulnerability), as shown in Table 1 , the following being the general form of the vulnerability index (Viseu [3]):

$$
I_{v u \ln }=\frac{100}{I_{\max }}\left(K_{4} I_{\text {edi }}+K_{5} I_{\text {soc }}+K_{6} I_{\text {eco }}+K_{7} I_{\text {prep }}\right)
$$

where $I_{\max }=4$ is the value of the maximum class and $K_{4}+K_{5}+K_{6}+K_{7}=1$. 
Table 1: $\quad$ Classes for vulnerability classification in flood prone areas.

\begin{tabular}{c|c|c}
\hline$I_{\text {vuln }}$ & Class & Meaning \\
\hline $0-20 \%$ & 0 & Vulnerability is not important \\
\hline $20.25-40 \%$ & 1 & The importance of vulnerability is reduced \\
\hline $40.25-60 \%$ & 2 & The importance of vulnerability is medium \\
\hline $60.25-80 \%$ & 3 & Vulnerability is important \\
\hline $80.25-100 \%$ & 4 & Vulnerability is very important \\
\hline
\end{tabular}

\section{Normalization of the vulnerability index indicators}

\subsection{Introduction}

The normalization of the indicators in a common scale is necessary because generally several indicators are measured in different units and scales. This normalization was done in the classic way by allocating each indicator its own risk class. Four classes were defined, varying in a scale from 0 to 4 , according to the proposal of EUROFLOOD [2].

\subsection{Physical household vulnerability sub-index}

The characteristics of the buildings constructed in the flood prone area define two main indicators, namely:

the material of the resistant elements of those buildings ( $\left.I_{\text {resist }}\right)$, which translates the building's capacity to resist the flood, analysing their hypothesis of only suffering submersion damages (no destruction) as well as giving an idea of their ability of being shelters during the flood (contributing to a decrease in the number of mortal victims);

the number of floors in the building ( $\left.I_{n p i s}\right)$, which also measures the real capacity of the buildings to be shelters for people remaining in the risk area during the flood (vertical evacuation).

The criteria to establish the different classes for the physical household vulnerability sub-index are resumed in Table 2.

The physical household vulnerability sub-index $\left(I_{e d i}\right)$ is obtained by the arithmetic average of the numerical value of the class defined for each of those two indicators:

$$
I_{\text {edi }}=\frac{I_{\text {resist }}+I_{n p i s}}{2}
$$


Table 2: Normalization of the indicators for the classification of the physical household vulnerability sub-index (Viseu [3]).

\begin{tabular}{c|c|c|c}
\hline \multicolumn{3}{c}{ Physical household vulnerability } \\
\hline $\begin{array}{c}\text { Indicator } \\
\begin{array}{c}\text { Percentage of buildings } \\
\text { whe concrete is the resistant } \\
\text { element material }\end{array}\end{array}$ & $I_{\text {resist }}$ & Indicator & $I_{n p i s}$ \\
Class & $\begin{array}{c}\text { Percentage of buildings with } \\
\text { more than one floor }\end{array}$ & Class \\
\hline $\begin{array}{c}\text { concrete buildings }>80 \% \\
60 \%<\text { concrete }\end{array}$ & 0 & $\begin{array}{c}\text { buildings }+1 \text { floor }>80 \% \\
60 \%<\text { buildings }+1 \\
\text { floor } \leq 80 \%\end{array}$ & 0 \\
buildings $\leq 80 \%$ & 1 & $\begin{array}{c}40 \%<\text { buildings }+1 \\
\text { floor } \leq 60 \%\end{array}$ & 1 \\
buildings $\leq 60 \%$ & $20 \%<$ buildings +1 & 2 \\
$20 \%<$ concrete & floor $\leq 40 \%$ & 3 \\
buildings $\leq 40 \%$ & 3 & buildings +1 floor $\leq 20 \%$ & 4 \\
\hline
\end{tabular}

Table 3: Normalization of the indicators for the classification of the economical vulnerability sub-index (Viseu [3]).

\begin{tabular}{c|c|c|c}
\hline \multicolumn{4}{c}{ Economical vulnerability } \\
\hline $\begin{array}{c}\text { Indicator } \\
\text { Illiteracy rate }\end{array}$ & $\begin{array}{c}I_{\text {analf }} \\
\text { Class }\end{array}$ & $\begin{array}{c}\text { Indicator } \\
\text { Unemployment rate }\end{array}$ & $\begin{array}{c}I_{\text {desemp }} \\
\text { Class }\end{array}$ \\
\hline illiteracy $\leq 5 \%$ & 0 & unemployment $\leq 3 \%$ & 0 \\
$5 \%<$ illiteracy $\leq 10 \%$ & 1 & $3 \%<$ unemployment $\leq 6 \%$ & 1 \\
$10 \%<$ illiteracy $\leq 15 \%$ & 2 & $6 \%<$ unemployment $\leq 9 \%$ & 2 \\
$15 \%<$ illiteracy $\leq 20 \%$ & 3 & $9 \%<$ unemployment $\leq 12 \%$ & 3 \\
illiteracy $>20 \%$ & 4 & unemployment $>12 \%$ & 4 \\
\hline
\end{tabular}

\subsection{Economical vulnerability sub-index}

The economical vulnerability sub-index $\left(I_{e c o}\right)$ is characterized by the following indicators:

the unemployment rate in the flood prone areas $\left(I_{\text {desemp }}\right)$, which gives an idea of the real life conditions of the population and also gives an idea of the economical recuperation capacity after the accident has occurred; the illiteracy rate of the population in the flood prone area ( $\left.I_{\text {analf }}\right)$, which is linked to the capacity to obtain employment as well as in accessing information and on the assimilation and adoption of civil protection preparedness measures.

The criteria to establish the different classes for the economical vulnerability sub-index are resumed in Table 3. 
The economical vulnerability sub-index $\left(I_{e c o}\right)$ obtained by the arithmetic average of the numerical value of the class defined for each of those two indicators is:

$$
I_{\text {eco }}=\frac{I_{\text {analf }}+I_{\text {desemp }}}{2}
$$

\subsection{Demographical vulnerability sub-index}

The demographical vulnerability sub-index $\left(I_{s o c}\right)$ is characterized by the following indicators:

the sum of the percentages of children and old people living in the flood prone area $\left(I_{m o b}\right)$, which translates to the mobility capacity of more vulnerable people and restricts the evacuation time;

- the number of social equipments and civil protection infrastructures localized in the flood prone area $\left(I_{\text {equi }}\right)$; this indicator identifies the 24 hour contact points, also evaluating the reaction time of civil protection agents.

The criteria to establish the different classes for the demographical vulnerability sub-index are resumed in Table 4.

Table 4: Normalization of the indicators for the classification of the demographical vulnerability sub-index (Viseu [3]).

Demographical vulnerability

\begin{tabular}{|c|c|c|c|}
\hline $\begin{array}{l}\text { Indicator } \\
\text { Rate of children and } \\
\text { old people } \\
\text { (Mobility) } \\
\end{array}$ & $\begin{array}{c}I_{m o b} \\
\text { Class }\end{array}$ & $\begin{array}{c}\text { Indicator } \\
\text { Number of social equipments and civil } \\
\text { protection infra-structures }\end{array}$ & $\begin{array}{l}I_{\text {equi }} \\
\text { Class }\end{array}$ \\
\hline $\begin{array}{c}\text { Mobility } \leq 20 \% \\
20 \%<\text { Mobility } \leq 30 \% \\
30 \%<\text { Mobility } \leq 40 \% \\
40 \%<\text { Mobility } \leq 50 \% \\
\text { Mobility }>50 \%\end{array}$ & $\begin{array}{l}0 \\
1 \\
2 \\
3 \\
4\end{array}$ & $\begin{array}{c}\text { Existence of hospitals, medical care } \\
\text { centres, police headquarters and } \\
\text { firemen headquarters } \\
\text { Existence of three of the former } \\
\text { buildings } \\
\text { Existence of two of the former } \\
\text { buildings } \\
\text { Existence of one of the former } \\
\text { buildings } \\
\text { There is no } 24 \text { hour contact point }\end{array}$ & $\begin{array}{l}1 \\
2 \\
3 \\
4\end{array}$ \\
\hline
\end{tabular}


The demographical vulnerability sub-index $\left(I_{s o c}\right)$ obtained by the arithmetic average of the numerical value of the class defined for each of those two indicators is:

$$
I_{s o c}=\frac{I_{m o b}+I_{e q u i}}{2}
$$

\subsection{Preparedness vulnerability sub-index}

The preparedness vulnerability sub-index $\left(I_{\text {prep }}\right)$ is directly linked to the emergency management practices in the flood prone area, either at the level of authorities and civil protection agents as well as at the population level. The criteria to establish the different classes for the preparedness vulnerability sub-index are resumed in Table 5.

Table 5: Normalization of the indicators for the classification of the preparedness vulnerability sub-index (Viseu [3]).

\begin{tabular}{c|c}
\hline Indicator & Class \\
\hline $\begin{array}{c}\text { Emergency planning practices and information } \\
\text { as well as preparation of population }\end{array}$ & $I_{\text {prep }}$ \\
\hline $\begin{array}{c}\text { Existence of Emergency Plan, preparation of civil protection agents } \\
\text { Existence of Emergency Plan but either the preparation of civil } \\
\text { protection agents is missing or there is no preparation of population } \\
\begin{array}{c}\text { Existence of Emergency Plan but no preparation of civil protection } \\
\text { agents as well no preparation of population }\end{array}\end{array}$ & 0 \\
$\begin{array}{c}\text { Population and agents have experience in coping with floods but } \\
\text { there is no emergency planning }\end{array}$ & 3 \\
No existence of any emergency planning practice & 4 \\
\hline
\end{tabular}

According to Table 5 the preparedness vulnerability sub-index is characterized by only one indicator - "emergency planning practices and information" - and considers the following aspects:

- $\quad$ the existence of an Emergency Plan for the flood prone area;

- $\quad$ the level of preparedness of authorities and civil protection agents in the flood prone area (occurrence of periodical exercises and tests);

- $\quad$ the knowledge level of the population concerning risk as well as behaviour and response to flood situations (public information and divulging). 


\section{Vulnerability index in Funcho and Arade dams flood prone area}

\subsection{Flood prone area characterization}

The Arade River is situated in the south-western part of Portugal in the Algarve region. The river basin has a surface area of $800 \mathrm{~km}^{2}$, being one of the most important Algarve main surface water resources. The flood prone area (Figure 1) was defined considered floods resulting from the failure of two dams localized in the river: the Funcho and Arade dams (Almeida et al., [1]).

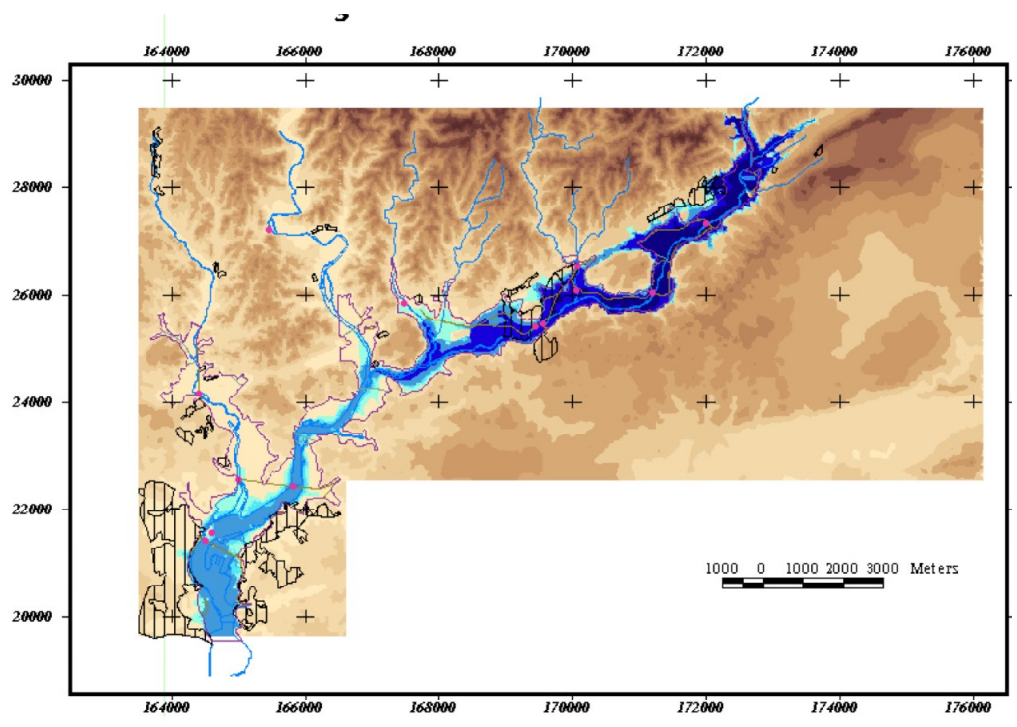

Figure 1: $\quad$ Funcho and Arade dams flood prone area.

The flood prone area was divided into three main areas in which the flood characteristics can be considered very different and defining a risk zoning. Those three main areas are the following:

- $\quad$ ZAS, the Immediate Security Zone, where the warning time is less than 0.5 hours;

ZIP, Principal Intervention Zone, where the warning time is less than 1.5 hours;

- $\quad$ ZIS, the Secondary Intervention Zone, where the warning time is greater than 1.5 hours.

Table 6 presents the information considering the economical and demographical characterization of these three main areas. 
Table 6: Characterization of Funcho and Arade dams flood prone area.

\begin{tabular}{|c|c|c|c|c|}
\hline Indicators & $Z A S$ & $Z I P$ & $Z I S$ & $\begin{array}{c}\text { Flood } \\
\text { prone area }\end{array}$ \\
\hline Number of people at risk & 885 & 6973 & 2544 & 10402 \\
\hline$\%$ persons $<15$ years old & 11.9 & 18.9 & 19.8 & 18.5 \\
\hline$\%$ persons $15-64$ years old & 63.5 & 67.0 & 67.5 & 66.8 \\
\hline$\%$ persons $>65$ years old & 24.6 & 14.1 & 12.7 & 14.7 \\
\hline$\%$ illiteracy & 30.6 & 16.8 & 15.2 & 17.6 \\
\hline$\%$ unemployment & 7.8 & 5.4 & 6.4 & 6.5 \\
\hline Number of buildings & 393 & 2231 & 626 & 3250 \\
\hline $\begin{array}{l}\% \text { buildings with more } \\
\text { one floor }\end{array}$ & 99.8 & 95.0 & 88.8 & 94.4 \\
\hline $\begin{array}{c}\% \text { of buildings where } \\
\text { concrete is the resistant } \\
\text { element material }\end{array}$ & 41.6 & 50.2 & 35.9 & 46.5 \\
\hline $\begin{array}{l}\text { Hospital or health care } \\
\text { centre existence }\end{array}$ & No & Yes & Yes & Yes \\
\hline $\begin{array}{c}\text { Firemen headquarters } \\
\text { existence }\end{array}$ & No & Yes & Yes & Yes \\
\hline $\begin{array}{c}\text { Police headquarters } \\
\text { existence }\end{array}$ & No & Yes & Yes & Yes \\
\hline
\end{tabular}

\subsection{Vulnerability index calculation}

An application using MS Excel software was developed for the vulnerability index calculation. Table 7 presents the table of results of this application giving the values of the vulnerability index for the Funcho and Arade dams flood prone area. It is possible to conclude that this vulnerability index is equal to $56.3 \%$.

It was also possible to verify that the most vulnerable zone in the flood prone area is also the zone where the flood danger is higher, ZAS ( $\left.I_{v u \text { In }}=75 \%\right)$. In terms of vulnerability, the ZAS zone is followed by the zone where the flood danger is lower, ZIS ( $I_{v u \text { ln }}=55 \%$ ). Finally, the less vulnerable zone is ZIP ( $I_{v u \text { In }}=60 \%$ ), being an intermediate zone in terms of flood danger, but benefiting from lower vulnerability, mainly due to having more recent and resistant buildings.

\section{Conclusions}

It is possible to conclude that the vulnerability index in the Funcho and Arade dams flood prone area is equal to $56.3 \%$, which, according to the significance of Table 1 corresponds to a community where the vulnerability has medium 
importance. The fact of having a new developed Emergency Plan for the valley downstream from the dams has positively contributed to decreasing the value of this index. Nevertheless, the vulnerability index can be important for some sub-areas of the flood prone area. Therefore, both the improvement of the life conditions of the population and the implementation of land-use management and restrictions according to the flood prone area risk zoning are important actions that could be envisaged. Non-structural measures, including emergency planning, warning and evacuation also constitute efficient ways to reduce vulnerability, as public participation and information are key aspects of the overall process of risk and vulnerability reductions in flood prone areas.

Table 7: Vulnerability index for the Funcho and Arade dams flood prone area.

\begin{tabular}{|c|c|c|c|c|c|c|c|}
\hline \multirow{2}{*}{\multicolumn{2}{|c|}{$\begin{array}{c}\text { Vulnerability } \\
\text { Physical } \\
\text { household }\end{array}$}} & \multirow[b]{3}{*}{0.30} & \multirow{3}{*}{$\begin{array}{c}\text { Indicator } \\
\text { Buildings material } \\
\text { Number of floors }\end{array}$} & \multirow{3}{*}{\begin{tabular}{|l|} 
Name \\
$I_{\text {resist }}$ \\
$I_{\text {npis }}$ \\
\end{tabular}} & \multirow{3}{*}{$\begin{array}{c}\text { Class } \\
2 \\
4\end{array}$} & \multicolumn{2}{|c|}{ Weight } \\
\hline & & & & & & $K$ & 0.5 \\
\hline & $3 \quad K_{4}$ & & & & & $K$ & 0.5 \\
\hline \multicolumn{2}{|c|}{ Demographic } & \multirow[b]{2}{*}{0.10} & $\begin{array}{l}\text { Rate of children and } \\
\text { elderly people }\end{array}$ & \multirow{2}{*}{$\begin{array}{l}I_{m o b} \\
I_{\text {equi }}\end{array}$} & \multirow{2}{*}{$\begin{array}{l}2 \\
0\end{array}$} & \multirow{2}{*}{$\begin{array}{l}K \\
K\end{array}$} & \multirow{2}{*}{$\begin{array}{l}0.5 \\
0.5\end{array}$} \\
\hline$I_{s o c}$ & $1 \quad K_{5}$ & & $\begin{array}{c}\text { Number of civil protection } \\
\text { buildings }\end{array}$ & & & & \\
\hline \multicolumn{2}{|c|}{ Economical } & \multirow[b]{2}{*}{0.10} & Illiteracy rate & \multirow{2}{*}{$\begin{array}{c}I_{\text {analf }} \\
I_{\text {desemp }}\end{array}$} & \multirow{2}{*}{$\begin{array}{l}3 \\
2 \\
\end{array}$} & \multirow[t]{2}{*}{ K } & \multirow{2}{*}{$\begin{array}{l}0.5 \\
0.5\end{array}$} \\
\hline$I_{\text {eco }}$ & $2.5 K_{6}$ & & Unemployment rate & & & & \\
\hline \multicolumn{2}{|c|}{ Preparedness } & \multirow[b]{2}{*}{0.50} & & & & & \\
\hline & $K_{7}$ & & & & & & \\
\hline \multicolumn{3}{|c|}{ Vulnerability index } & & & & \multicolumn{2}{|c|}{$I_{v u l n} 56.3 \%$} \\
\hline
\end{tabular}

\section{References}

[1] Almeida, A. B., Ramos, C. M., Santos, M. A. and Viseu, T. - "Dam break flood risk management in Portugal". National Laboratory of Civil Engineering publication, Lisbon Portugal, 2003.

[2] EUROFLOOD - "Questionnaire on the identification of significant parameters in flood damage assessment". Part 0 - Introduction of internal report, 1995.

[3] Viseu, T. - "Dams and safety of downstream valleys. Development of risk management support methodologies". PhD Thesis. Technical University of Lisbon, 2006 (in Portuguese). 